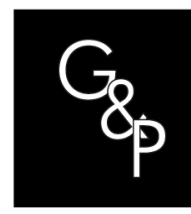

\title{
Perceived quality and loyalty in service operations: a study in banking segment's corporate person division
}

\author{
Qualidade percebida e lealdade em operações de serviço: \\ um estudo no setor bancário no segmento pessoa jurídica
}

\author{
Marcio Vanderlei Saueressig ${ }^{1}$, Fabiano Larentis ${ }^{2}$ (), Cintia Paese Giacomello ${ }^{3}$ (1) \\ ${ }^{1}$ Profissional de Instituição Financeira, Lajeado, RS, Brasil. E-mail: mvsaueressig@gmail.com \\ ${ }^{2}$ Universidade de Caxias do Sul - UCS, Programa de Pós-Graduação em Administração (PPGA), Área do \\ Conhecimento de Ciências Sociais, Caxias do Sul, RS, Brasil. E-mail: flarenti@ucs.br \\ ${ }^{3}$ Universidade de Caxias do Sul - UCS, Programa de Pós-Graduação em Administração (PPGA) e Programa de \\ Pós-Graduação em Engenharia de Produção (PPGEP), Área do Conhecimento de Ciências Exatas, Caxias do \\ Sul, RS, Brasil. E-mail: cpaese1@ucs.br
}

How to cite: Saueressig, M. V., Larentis, F., \& Giacomello, C. P. (2021). Perceived quality and loyalty in service operations: a study in banking segment's corporate person division. Gestão \& Produção, 28(1), e4934. https://doi.org/10.1590/1806-9649.2020v28e4934

\begin{abstract}
This study aims to verify the relationship between perceived service quality and loyalty among corporate customers of a bank located in the southern region of Brazil. Two research stages were developed, one qualitative exploratory and the other quantitative descriptive. The qualitative stage aimed to collect managers' and customers' perceptions about the bank services. This stage has been developed through semi-structured in-depth interviews, which provided input to improve the collection instrument applied in the quantitative stage. A survey with 48 questions was applied to 129 customers, based on SERVPERF service quality scale, Santos' loyalty scale (2001) and questions added from qualitative stage. The qualitative stage has contributed with a proposal of scale adapted to the current context of the banking sector, corporate customers . In the quantitative stage, through multiple regression analysis, we have identified that empathy, safety and response factors, in descending order of importance, have had a greater impact on loyalty, with a power of explanation of $62 \%$. Additionally, through ANOVA, the results allow us to conclude that means are higher among customers with a longer relationship with the bank, among customers who operate with credit and who have the bank as the main financial institution in terms of investments.
\end{abstract}

Keywords: loyalty; perceived quality; banks.

Resumo: Este estudo teve como objetivo verificar a relação existente entre a qualidade percebida do serviço e a lealdade dos clientes pessoa jurídica de uma instituição bancária na região sul do Brasil. Para tanto, desenvolveram-se duas etapas de pesquisa, uma qualitativa exploratória e outra quantitativa descritiva. A etapa qualitativa, através de entrevistas semiestruturadas em profundidade teve como propósito coletar percepções de gestores e clientes do banco, que proporcionassem subsídios para o aprimoramento do instrumento de coleta aplicado na etapa quantitativa. Através de uma survey, foi aplicado um questionário com 48 questões em 129 clientes, cuja escala de qualidade de serviços SERVPERF e a escala de

Received Jul. 19, 2019 - Accepted Mar. 17, 2020

Financial support: None.

This is an Open Access article distributed under the terms of the Creative Commons Attribution License, which permits unrestricted use, distribution, and reproduction in any medium, provided the original work is properly cited. 
lealdade de Santos (2001) tiveram adicionadas 20 questões oriundas das entrevistas da etapa qualitativa. Como resultados, a etapa qualitativa contribuiu com uma proposta de escala adaptada para o contexto atual do setor bancário clientes PJ. Na etapa quantitativa, através da análise de regressão múltipla, os fatores empatia, segurança e resposta, em ordem decrescente de importância, mais impactaram na lealdade, com um poder de explicação de $62 \%$. Adicionalmente, com a ANOVA, os resultados permitem concluir que as médias de avaliação são mais elevadas para clientes com maior grau de relacionamento com o Banco, envolvendo os que operam com crédito e que tinham o banco como principal instituição financeira em volume de negócios.

Palavras-chave: lealdade; qualidade percebida; bancos.

\section{Introduction}

As a national economy develops through productivity increase and automation in agriculture and industry, the relative participation of employment among agriculture, industry and service sectors changes drastically (Lovelock \& Wirtz, 2006), giving more space to services in GDP composition. In Brazil, 73\% of 2017's GDP pertains to services (IBGE, 2018). Worldwide, according to 2017's estimates, services represent $63 \%$ of wealth, and countries as USA, France, Netherlands and United Kingdom services account for around $80 \%$ of their GDPs (CIA, 2018).

In regard to importance of services, we have specificities related to services management, which are imprecise, unstructured, multidimensional and complex. Nature of services considers challenges inherent to activities generally more laborintensive, less sensitive to economies of scale, with larger quality variations and, in most of times, smaller productivity and profit rates (Larentis et al., 2013; Roth \& Menor, 2003).

In that context, Johnston \& Clark (2002) draw attention to the operational complexity of services, which has origin in aspects such as interconnectivity, size, structure, uncertainty, time, interdependency and services nature. Service operations, as frontline as well as back stage office activities, involve people, processes, structures and systems (Grönroos, 2009; Johnston \& Clark, 2002).

Hence, in a complex scenario of management and operations, service quality arises as an opportunity of differentiation in competitive markets (Karatepe, et al., 2005; Tan et al., 2017). On the other hand, service operations and customer relationship are two-way streets, which allow suppliers the possibility of enough profitability for business sustainability and also allows customer the opportunity to satisfy their needs and wishes, thus representing an effective business strategy (Fitzsimmons \& Fitzsimmons, 2014; Heskett, 2002; Reguera-Alvarado et al., 2016; Reichheld \& Sasser, 1990; Tan et al., 2017).

The banking sector is not different. It presents a larger involvement between providers and customers, as well as a permanent change in customer needs and technology, which demands fast restructuring in order to achieve markets and new technologies (Ribeiro et al., 2010; Zacharias et al., 2008). In this regard, RegueraAlvarado et al. (2016) highlight that banks are constantly searching for new ways to add value to their services, since financial services compete in a global market with generally undifferentiated products. Thus, service quality can be faced as an inestimable asset that banks need to manage in order to survive and gain competitive advantages (Kranias \& Bourlessa, 2013). 
Al-Hawari (2015) reinforces the importance of service quality for banking industry performance and says that diverse scholars have shown the relation between perceived quality and other Marketing constructs, such as loyalty. For Mittal \& Gera (2012), it is critical for banking executives and services researches to define that service quality constructs influence behavior outcomes, among them loyalty. Hence, in this research we verify the relation between perceived service quality and customer loyalty in a Brazilian southern bank. Moreover, we identify relationship features with the bank that affect quality and loyalty perceptions.

This research is justified, firstly, by investigating an activity that represented in 2017 $11 \%$ of services sector in Brasil, including finance, insurance and related businesses (IBGE, 2018). Moreover, it deals with services quality in banking sector, which since 2010 has aroused more research interest (Abdullah et al., 2011; Ensslin et al., 2013), although services quality studies have been relevant in the last thirty years (Mangini et al., 2017).

In addition, concerning service operations, it contributes to enlarge the comprehension about the relation between service quality and loyalty, which has been presenting somewhat inconsistent results (Kranias \& Bourlessa, 2013). In such case, as Kranias \& Bourlessa (2013), who study Greek banking sector, we have opted for verifying the direct relation between service quality and loyalty, instead of the indirect relation, generally mediated by satisfaction (Baumann et al., 2017; Dahiyat et al., 2011; Jaiswal \& Lemmink, 2017; Makanyeza \& Chikazhe, 2017; Mittal \& Gera, 2012; Pattanayak et al., 2017). Lastly, we have investigated the corporate person division, unlike other studies, which focus in end-consumers.

\section{Literature review}

\subsection{Service operation}

Most definitions of service have in common aspects as intangibility and simultaneity. Customer participation in the "production" process is one of the main differences compared to manufacturing (Fitzsimmons \& Fitzsimmons, 2014). Customer presence entails complexity to operation management, intangibility makes service quality difficult to be managed, heterogeneity makes customer expectations different and perishability constrains services in demand peaks (Prajogo, 2006; Fitzsimmons \& Fitzsimmons, 2014).

For Chase \& Apte (2007), manufacturing can make use of technological resources and apply engineering principles to improve quality and enlarge capacity, achieving more productivity and profit margins. Service operation, however, presents an intense degree of interaction with customers, a greater intensity of labor and a smaller sensitivity to economies of scale, which generate larger quality variations and lesser productivity levels in comparison to manufacturing (Chase et al., 1998; Chase \& Apte, 2007; Larentis et al., 2013). Furthermore, balance between capacity and demand in service operations is not easy, and successful managerial initiatives can make all the difference (Chase \& Apte, 2007; Lovelock \& Wirtz, 2006).

In this context, service operations develop in two interdependent components: frontline and backstage office, or support (Grönroos, 2009). In front office we have the presence of service encounters, called by Carlzon (2005) moments of truth, which 
means the period of time in which a customer interacts with a service provider, involving people, processes, structures and systems.

Barreto \& Martins (2018), identified four main sources when they approached variability originated from customer participation: customer arrival, needs diagnoses, solution providing and analysis of delivered value. The authors conclude that professional service companies prioritize customer participation. This requires variability accommodation in flexible operations in order to meet different customer groups, which makes difficult an alignment with the growth strategic planning.

Moreover, in spite of differences between manufacturing and services, methodologies and tools of industrial management allow to promote the effectivity of service operations. Johnston (2005) stresses the need to take into account productivity, efficiency and quality aspects. There are evidences of the suitable use of manufacturing principles in health services (LaGanga, 2011). Despite technological evolution, it has been difficult to find automatized systems capable to deal with high variability of customer demands, customized offers and capacity to deal with exceptions (Ponsignon et al., 2011).

\subsection{Perceived service quality and means of measurement}

Service quality presents a robust influence not only on business operations and their profitability, but also on customers' satisfaction and loyalty (Malik et al., 2011). According to Zeithaml et al. (2014), customers complexly perceive services in terms of quality and how satisfied they are about the whole set of experiences. Then, for developing a management and marketing model, it is important to understand what customers are searching for and evaluating. Quality, which is a judgment about the global excellence or superiority or an offer, ceases to be only an internal goal (Zeithaml, 1988; Grönroos, 2009). Service quality, furthermore, is multidimensional and difficult to be evaluated (Mangini et al., 2017).

In this concern, Parasuraman et al. (1985) proposed a conceptual framework of service quality based on the range of discrepancy between customers' perceptions and expectations, also known as Gaps framework. Based on it, in a further study Parasuraman et al. (1988) developed the SERVQUAL scale, resulting in five factors of service quality: tangibles (physical aspects), reliability (capability of providing reliable services and with expected performance), responsiveness (willingness to help, with agility), assurance (solving customers' doubts, without providing a sensation of the existence of excessive risks) and empathy (recognizing the need of a differentiated service according to customers' needs and aspects). SERVQUAL scale is applied through 22 statements, taking into account both expectations and perceived performance. The degree of confirmation associated to expectations defines the customer's perceived quality.

Cronin \& Taylor (1992), by questioning the fact service quality is determined by the discrepancy between expectations and experimented results by customers, proposed a service quality framework based only on the perception of service performance, without considering customer expectations. That scale is named SERVPERF, with the same 22 SERVQUAL items. The authors concluded that SERVPERF scale is more sensitive in depicting quality variations. Parasuraman et al. (1994) retorted Cronin \& Taylor's criticisms, who contested those objections in 1994.

Several other frameworks have been presented for the two last decades, but somewhat originated from those two theoretical proposals (Seth et al., 2005). Robledo 
(2001) highlights the aspect of conflicting paradigms that these two approaches show. Gaps model is known as paradigm of disconfirmation, while the opposing proposal is calleda paradigm of perception (Robledo, 2001). In this regard, Souto \& Correia-Neto (2017) reinforce that SERVPERF presents similar consistency to SERVQUAL and smaller cost and time of operationalization. Even so, their desk research founded that about $90 \%$ of empirical papers applied SERVQUAL scale.

Laslty, as presented by Mangini et al. (2017), we highlight that consumer's actions and reactions are not sedimented only in the comparison between expected and performed services, but also in association to emotions, tangible aspects and service provider's behavior. Moreover, the stronger the front-line employee's commitment, the better the service quality will be. Also, the more aligned the front-line employee's and consumer's behavior, the greater the customer satisfaction.

\subsection{Loyalty in services}

Services are inherently relational, regardless of the means they are provided (Grönroos, 2009), reinforcing the importance of defining how to develop relationships with customers in consideration to service operation (Roth \& Menor, 2003). As stated by Aksu (2006), loyalty presents more importance in services, once we have more opportunities of interactions between people, which enable more opportunities to develop loyalty (Parasuraman et al., 1985).

According to Oliver (1999), loyalty is a profound and consistent commitment to repurchase a product/service in the future, which generates repeated purchases of a specific brand, even with situational influences and marketing efforts which are capable to cause behavior changes. For Sirdeshmukh et al. (2002), consumer loyalty is defined as a behavioral intention to maintain a long-lasting relationship with a service provider. Other definitions are related to repeated behavior and the role of commitment associated to brand (Assael, 1992), an implicit or explicit promise for maintain a relationship (Oliver, 1999) and an attitude of preferring a determined service provider (Gremler \& Brown, 1996).

Therefore, loyalty is associated not only to repurchase behavior, but also to positive attitudes in relation to a service provider, such as recommendations and word-ofmouth, in other words, as behavioral as well as attitudinal perspectives (Mangini et al., 2017). In this regard, by examining attitudinal loyalty, one can classify purchases in those related to other brand's unavailability in comparison to a commitment associated to a determined brand (Jaiswal \& Lemmink, 2017).

Oliver (1999) settles that loyalty develops in four stages, in which consumers become loyal in a cognitive sense, in a first moment, going through affective and conative stages until at last present a behavior of consumption per se:

a) cognitive loyalty: consumer preference is based on cognition, where a customer, with available information, defines their preferences of purchasing in relation to a brand stemming from available options in market;

b) affective loyalty: based on affect due to a positive attitude in relation to a brand, after successive and cumulated satisfactory experiences from repeated purchasing situations or uses;

c) conative, or instinctive loyalty: there is a customer's behavioral intention, reflecting on a profound commitment to purchase - while affection suggests motivational 
elements, commitment of intention reflects on a wish to execute determined action (purchasing);

d) Action loyalty: intention converted to purchasing.

On the other hand, Gremler \& Brown (1996) define loyalty in services based on three dimensions: (1) behavioral: degree of disposition to repeat a consumption behavior; (2) attitudinal: disposition of a positive attitude in relation to a service provider; and (3) cognitive: customer considers to use only an specific provider when is necessary. Loyalty is generally understood as consisted by behavioral and attitudinal dimensions: repurchase, less sensitivity to prices, creation of affective bonds and recommendations through positive word-of-mouth (Santos \& Fernandes, 2006).

With higher levels of loyalty, a company is able to enlarge market share, reduce operational and marketing costs and increase profitability (Ladhari et al., 2011; Reichheld, 1996). Loyalty can mean to companies the achievement of competitive advantages and better performance, being a central concern to marketers (Oliver, 1999; Visentini \& Fenner, 2017).

\subsection{Perceived quality, satisfaction and loyalty in banking services}

Atracting a new consumer is more expensive than retaining a current one. Bank professionals are searching for comprehending the main determinants of customer's satisfaction and loyalty (Kaura et al., 2015, Balbim \& Bornia, 2011). Taking into account that the nature of financial services since their main offers are intangible, the result is the investment they mean, as well as peripheral offered services, which stresses the importance of complimentary services from financial offers as fundamental factor of satisfaction (Zacharias et al., 2008). Satisfaction, trust and commitment, in other words, the level of quality of relationship between customer and banks develops based on successful service encounters, mainly those face to face (Reguera-Alvarado et al., 2016).

In this context, in correspondence to SERVQUAL/SERVPERF's constructs, Abdullah et al. (2011) have identified that quality of banking services is characterized by four constructs:

service deliver systematization (organization and procedures in services), reliable communication (provide services and communicate it with a comprehensive, professional and empathic means) and responsiveness (availability to help and agility), being systematization that which achieve the greater importance on quality in general. Dahiyat et al. (2011) have identified three dimensions: reliability, quality of interaction (involving responsiveness, assurance and empathy) and tangibles. Lee et al. (2011) have considered capability, active information offer and assurance. Mittal \& Gera (2012) have taken in consideration the dimensions of service systems (human and technological) and central services/offers. Kaura et al. (2015) have investigated with employee's behavior, information technology, convenience of decision, transaction and benefits. Hamzah et al. (2017), on the other hand, have identified, besides four SERVQUAL/SERVPERF's constructs, the internet banking construct.

In this regard, Pattanayak et al. (2017) have identified the need, in total quality programs in banks, to emphasize the quality of leadership, suitability of information systems and adaptation to technologies and service environments. Still, the importance of employee and customer orientation and the need of benchmarking. That will improve service quality and market orientation, which will impact in customer's satisfaction and 
loyalty levels. Tan et al. (2017) highlight the role of employees in representing bank as a whole, warranting service accuracy and as key-elements for customers' evaluation of quality.

Therefore, banking service quality will affect positively costumer's trust and satisfaction, as well loyalty (Dahiyat et al., 2011; Bapat, 2017; Hamzah et al., 2017; Tan et al., 2017), which contributes to profitability (Dahiyat et al., 2011). This is because customers' satisfaction depends, at least in part, on the means as a bank interacts with customers and how manages the relationship, involving both managers' service and resolution of customers' problems (Zacharias et al., 2008). In this sense, Makanyeza \& Chikazhe (2017) reinforce the need of banks to structure loyalty programs integrated to service quality, customer's satisfaction and corporate image.

Service quality, which is central to the achievement of greater levels of loyalty, should be related to customers' needs (Tan et al., 2017). The positive impact of banking service quality on satisfaction and loyalty have been identified by several studies (Dahiyat et al., 2011; Bapat, 2017; Hafeez \& Muhammad, 2012; Hamzah et al., 2017; Jaiswal \& Lemmink, 2017; Kaura et al., 2015; Ladhari et al., 2011; Makanyeza \& Chikazhe, 2017; Mittal \& Gera, 2012; Tan et al., 2017). We highlight the mediator role of satisfaction in the relation between quality and loyalty ((Kaura et al., 2015; Mangini et al., 2017).

In order to specify such relations, Bapat (2017) have identified that both easiness of use, associated to technological aspects, and service quality in a bank branch, interfere in satisfaction and, indirectly, in loyalty. In study of Hafeez \& Muhammad (2012), the impact of service quality on loyalty was more than doubled that the impact of satisfaction on loyalty, and almost doubled that fidelity programs. Jaiswal \& Lemmink (2017) have verified the impact of quality on satisfaction, taking both to attitudinal loyalty and disposition to pay more. In Ladhari et al. (2011), perceived quality has presented direct effect on behavioral and attitudinal loyalty, and indirect effect through satisfaction and trust.

Regarding specifically the relation between constructs of quality and loyalty, Malik et al. (2011) have identified that tangibles, assurance and empathy, in decreasing order in terms of importance, but not reliability and responsiveness, contributes to enlarge loyalty. Lee et al. (2011) have identified the positive impact of capability, active information offer and assurance. Mittal \& Gera (2012) have verified that service quality impacts positively both on intentions of recommendation and intentions to continue to use the service, in which the indirect path, through satisfaction and value, is weaker. Furthermore, the system of service delivering affects directly intentions of recommendation (attitudinal loyalty) and the aspects of service affect directly repurchasing intentions (behavioral loyalty). On the other hand, according to Kranias \& Bourlessa (2013), customers will visit a bank branch more frequently if the bank location will be convenient, interfering in loyalty.

For Kaura et al. (2015), employee's behavior, information technology, convenience of decision, transaction and benefits, price and perceived fairness have significant effect on loyalty, in which satisfaction this relation. Results of Jaiswal \& Lemmink (2017) have indicated that superior service quality takes to customer's satisfaction and attitudinal loyalty, through intentions of repeated purchases, intention of word-of-mouth and customer's advocacy. Coefficients of attitudinal loyalty's effect on disposition to pay more are relatively smaller than coefficients of the antecedent relations, which may mean that consumers are not willing to pay a premium price beyond determined point, and that managers need to invest in better services considering effective costs. 
On the other hand, as study of Baumann et al. (2017), perceptions associated to bank competitiveness, as regulation as stability, affect the relation between loyalty vectors and loyalty per se, going beyond the relation between satisfaction and service quality and loyalty. Study of Pattanayak et al. (2017) reinforces the importance of total quality management tools for stronger degrees of market orientation, better customer services and more satisfaction, to get more loyalty.

Lastly, taking into account specific features of banking customers, Seiler et al. (2013) have identified that customers with more investments present greater levels of satisfaction and loyalty. According to Bapat (2015), customers with more than one bank account generally maintain more transactions with the most preferred banks, give more importance to technology, have payroll account or pension and long term relationships, in other words, a stranger relation with loyalty. For customers with more investments, according to Reguera-Alvarado et al. (2016), use of e-banking does not influence relationship quality, as they acquire the power of personalized attention in banking services. As presented by Bapat (2017), physical branches emerge as the favorite channel for emotional interactions, in which human interactions perform an important role.

In regard to customers' personal values (security, social affiliation, growth and achievement) and their relation to the four stages of loyalty (cognitive, affective, conative and action), Henrique \& Matos (2015) have verified that only values of growth and achievement influence significantly the four stages, whose people present less probability to be loyal to a specific bank. These effects are more visible in women, because they tend to search more variety than men, and in older and richer people (educational degree does not moderate). In general, older and richer people tend to be more loyal, since they do not present values of growth and achievement.

\section{Methodological procedures}

We performed a research with two stages: a qualitative and a quantitative stage. The results from qualitative stage served to refine SERVPERF scale, from Cronin \& Taylor (1992), with similar consistency compared to SERVQUAL and less time for operationalization (Souto \& Correia-Neto, 2017), applied in a bank, which generate the collection instrument used in the quantitative stage. This strategy of sequential research is suggested by Creswell (2010).

The qualitative stage was developed by semi-structured in-depth interviews performed with six banks' branch managers (with an average work time of 19 years) and three customers corporate person (general managers, with an average of 14 years of relationship with the bank). The interview script was developed taking into account the categories service quality, operations (front-line office and back office) and loyalty. Interviews were performed personally between November 2014 and March 2015, with an average duration of 55 minutes, transcribed simultaneously. The number of interviews' definition considered the saturation criteria. Further, content analysis was adopted, in which we considered the steps of prior analysis, exploration of material and treatment of results (inferences and interpretation) (Bardin, 2011; Flick, 2009).

For the second stage (quantitative research), the collection instrument was created based in four different sources: (i) 18 statements of quality from qualitative research, (ii) 22 statements from SERVPERF scale, (iii) 7 statements related to loyalty, from Santos (2001) and (iv) characterization questions. Statements which presented redundancy between interviews' results, SERVPERF and loyalty scales were 
suppressed. Also, the term "modern equipments" from SERVPERF was changed to "working perfectly".

We chose these criteria due to the research's specificity (corporate person) and aspects associated to technology in banking sector. Statements were presented to respondents with a seven-point type Likert scale, from 1 totally disagree to 7 totally agree. The instrument was validated by three experts, doctors in Management. After that, we performed a pre-test with five bank's customers.

For collection, the sample was composed para corporate person customers from a bank located in one of the largest towns in Brazil's southern region, through a non probabilistic by convenience procedure, in which companies participated since the had movement in the bank's account. Questionnaires, printed, was delivered to the customers and collected by the researches after one week. We also performed an electronic survey, based on e-mails' lists. We obtained 134 responses, being 63 from electronic survey and 71 from printed questionnaires. We did not identify difficulties to fill-in the collection instrument. We performed ANOVA analysis in order to compare the two ways of collection, and we did not identify significant statistically differences, which allowed us to use all the questionnaires conjointly.

About quantitative data analysis, with SPSS 22, we considered descriptive statistics, factor analysis to identify and validate factors, multiple regression analysis to verify the relations between perceived quality and loyalty, and ANOVA to evaluate statistic differences between means from two or more groups of respondents (Collis \& Hussey, 2005; Hair et al., 2009; Malhotra, 2012).

In data preparation, we performed missing data analysis, outliers and distribution analysis. Firstly, five cases were eliminated due to missing answers more than $10 \%$ of statements, and missing values below this criterion were replaced by variable mean (Hair et al., 2009). We did not identify multivariate outliers through Mahalanobis distance procedure (D2/df less than 3), according to Hair et al. (2009).

Normality analysis was performed taking into consideration asymmetry and kurtosis values, which ranged from de -1.665 a -0.22 and -1.019 a 2.805, respectively, below the maximum of modulus 3 (asymmetry) and 10 (kurtosis) (Kline, 2011). For homoscedasticity analysis, we considered the Levene's test (Hair et al., 2009) for four non-metric variable groups: customers that issue bank payments slips, that operate with credit, that uses internet in transactions and that work with other banks. Some of this non-metric variables, when considered as dependents, pointed out to some statements with levels of significance smaller than 0.05 , however we did not observe a pattern of heteroscedasticity, with exception of V35 variable in two groups. Even so, it was maintained, by considering that the lack of consistent patterns to each metric variable suggests that implications are minimal (Hair et al., 2009).

Lastly, we verified linear relations between variables, through Person's correlation coefficient. Results indicated positive correlation between variables, in a range between 0.108 and 0.917 significant correlations. Multicollinearity analysis was performed by considering Pearson's correlations above 0.85 and variance inflation factor (VIF) above 10 (Hair et al., 2009). Both criteria indicated the exclusion of variables, 43, 44 e 48, from loyalty scale. After these exclusions, we achieved a 2.93 ratio of responses by variable, for 129 responses. 


\section{Results}

\subsection{Qualitative stage}

We have initially defined two categories of analysis stemming from the interviews performed - service operation from front-line office and service operation from back office, besides loyalty. We have applied two data reductions (Flick, 2009). In Chart 1 we present the respective results, which have contributed with 18 statements to the instrument of collection, taking into account features of front-line office and back office.

Chart 1. Qualitative Results (2nd reduction).

\begin{tabular}{|c|c|}
\hline FRONT-LINE OFFICE & BACK OFFICE \\
\hline - Convenience of business hours; & - No need to go to the branch for documents signing; \\
\hline $\begin{array}{l}\text { - Trust in the person who helps } \\
\text { me; }\end{array}$ & - Account debits with prior authorization; \\
\hline $\begin{array}{l}\text { - Confidence when solving } \\
\text { customer doubts; }\end{array}$ & - Availability of resources for immediate credit operations; \\
\hline $\begin{array}{l}\text { - Concern about solving } \\
\text { customer problems; }\end{array}$ & - Updating of registration and accounting numbers; \\
\hline $\begin{array}{l}\text { - Reduced turnover of } \\
\text { employees and managers; }\end{array}$ & - Effective monitoring of the need and grant of guarantees; \\
\hline - Easy use of internet banking; & - Correct credit grant operations contracts \\
\hline - Pre-approved credit limits; & - No loss of customer documents \\
\hline $\begin{array}{l}\text { - Autonomy of branch } \\
\text { managers to act; }\end{array}$ & - Availability of documents that require timely research \\
\hline $\begin{array}{l}\text { - Availability of sufficient } \\
\text { employees for face-to-face } \\
\text { service; }\end{array}$ & - Timely provision of returned checks \\
\hline - Appropriate physical structure; & - Compliance in bank procedures for overdue payments \\
\hline - ATMs working perfectly; & \\
\hline - Perception of customer needs; & \\
\hline $\begin{array}{l}\text { - Employees who prioritize } \\
\text { customer's presence; }\end{array}$ & \\
\hline $\begin{array}{l}\text { - Availability of information on } \\
\text { customer service alternatives; }\end{array}$ & \\
\hline $\begin{array}{l}\text { - Sale of products that meet the } \\
\text { real needs of customers; }\end{array}$ & \\
\hline $\begin{array}{l}\text { - Discretion and privacy in } \\
\text { customer service; }\end{array}$ & \\
\hline - Courtesy and cordiality; & \\
\hline $\begin{array}{l}\text { - Transparency and clarity of } \\
\text { information; }\end{array}$ & \\
\hline $\begin{array}{l}\text { - Employees with knowledge of } \\
\text { the specifics of services; }\end{array}$ & \\
\hline - Regular visits to customers; & \\
\hline - Safe internet banking; & \\
\hline $\begin{array}{l}\text { - Feedback to the customer on } \\
\text { pending claims; }\end{array}$ & \\
\hline $\begin{array}{l}\text { - Fulfillment of promises and } \\
\text { deadlines. }\end{array}$ & \\
\hline
\end{tabular}




\subsection{Quantitative stage}

\subsubsection{Characterization of the sample}

The sample was constituted of 129 financial managers from companies that pertain $54.8 \%$ to commerce segment, $23,8 \%$ to industry and $21.4 \%$ to services; $43.2 \%$ of these companies have up to 9 employees, $28.8 \%$ from 10 to 20 employees, resulting in $72 \%$ with up to 20 employees, $19.2 \%$ from 21 to 100 and $8.8 \%$ more than 100 employees. Regarding relationship length, $14.3 \%$ have accounts for less than 2 years, $18.3 \%$ between 2 and 5 years, $23.0 \%$ between 5 and 10 years and $44.4 \%$ more than 10 years.

Most of the companies work with other banks (81.9\%), operate with credit $(77.0 \%)$ and use internet banking (74.6\%), issue bank payments slips $(56.3 \%)$ and need bank teller service $(56.7 \%)$. For $58.4 \%$, the researched bank is the main bank in business amount. About the frequency in the branch to discuss company's matters, we have observed a mean of once a week. About bank managers' frequency of visits, a mean of twice a month.

\subsection{Validation of scales}

We have considered the exploratory aspect of factor analysis, since its objective is to gather variables related to perceived quality with strong inter-relation, which determined the factors of analysis. We have executed the same procedure to loyalty variables in order to verify if them would gather in an only factor.

After the analysis of factor loadings we have defined a new structure of factors. We have maintained the five original factors from SERVPERF. Moreover, we have added a sixth factor, named "Internet", because of its importance in banking services. Such factor also was considered by Hamzah et al. (2017). SERVPERF variables V12 and V14 and Stage Qualitative Variables V5, V30 and V37 have been eliminated once they have presented factor loadings lower than 0.45, according to Hair et al. (2009). Therefore, we have got a set of 35 quality variables, some of which gathered in different factors when compared with the original SERVPERF scale, presented in Table 1.

After factor extraction, we have performed Cronbach's Alpha test to evaluate the instrument of collection's reliability. Alphas values for quality factors have ranged from 0.782 to 0.949 and for loyalty factor 0.917 , classified as suitable by Hair et al. (2009).

Table 1. Quality Factors.

\begin{tabular}{llc}
\hline \multicolumn{1}{c}{ FACTOR } & \multicolumn{1}{c}{ VARIABLES } & LOADING \\
\hline TANGIBLES & V2 Bank's physical facilities are visually attractive. & 0.782 \\
\hline$\alpha=0.826$ & V3 Bank employees are well dressed and tidy. & 0.641 \\
\hline & $\begin{array}{l}\text { V4 Bank's physical facilities have a suitable } \\
\text { appearance. }\end{array}$ & 0.852 \\
\hline RELIABILITY & $\begin{array}{l}\text { V8 When the Bank promises to do something at a } \\
\text { certain time it does. }\end{array}$ & 0.620 \\
\hline$\alpha=0.840$ & $\begin{array}{l}\text { V11 The Bank provides the service in the promised } \\
\text { time. }\end{array}$ & 0.697 \\
& $\begin{array}{l}\text { V32 I do not feel pressured to purchase products that } \\
\text { do not meet my company's real needs. }\end{array}$ & 0.538 \\
\hline
\end{tabular}


Table 1. Continued...

\begin{tabular}{|c|c|c|}
\hline FACTOR & VARIABLES & LOADING \\
\hline & $\begin{array}{l}\text { V36 The release of credit operations grant occurs } \\
\text { immediately after the settlement of the contracts. }\end{array}$ & 0.601 \\
\hline & $\begin{array}{l}\text { V38 Requests for bank payments slips instructions are } \\
\text { promptly met. }\end{array}$ & 0.556 \\
\hline RESPONSIVENESS & $\begin{array}{l}\text { V13 Employees / Managers remain long enough in the } \\
\text { branch to establish relationships with clients. }\end{array}$ & 0.713 \\
\hline \multirow[t]{11}{*}{$\alpha=0.949$} & V15 I am immediately assisted by Bank employees. & 0.563 \\
\hline & V16 Bank staff is always willing to help me. & 0.759 \\
\hline & $\begin{array}{l}V 17 \text { Bank staff are always available to respond to my } \\
\text { requests. }\end{array}$ & 0.787 \\
\hline & $\begin{array}{l}\text { V18 My manager visits me frequently enough to meet } \\
\text { the company's needs. }\end{array}$ & 0.710 \\
\hline & $\begin{array}{l}\text { V19 The Bank keeps me informed of the service } \\
\text { alternatives (Internet, Self-service, etc). }\end{array}$ & 0.504 \\
\hline & $\begin{array}{l}\text { V23 Bank employees receive adequate support to fulfill } \\
\text { their tasks properly. }\end{array}$ & 0.624 \\
\hline & $\begin{array}{l}\text { V24 Bank employees have knowledge about service } \\
\text { specificities. }\end{array}$ & 0.535 \\
\hline & V25 The Bank gives me individual attention. & 0.748 \\
\hline & V26 Bank staff gives personal attention to me. & 0.705 \\
\hline & V31 Meeting the needs of my company is quick. & 0.627 \\
\hline & $\begin{array}{l}\text { V34 When I need a document, it is immediately } \\
\text { available to me. }\end{array}$ & 0.529 \\
\hline ASSURANCE & $\begin{array}{l}\text { V1 The Bank has equipment (ATMs and computers) } \\
\text { working perfectly. }\end{array}$ & 0.573 \\
\hline \multirow[t]{5}{*}{$\alpha=0.819$} & V10 The Bank is reliable. & 0.537 \\
\hline & V20 You can believe in Bank employees. & 0.513 \\
\hline & $\begin{array}{l}\text { V21 You feel secure in negotiating with Bank } \\
\text { employees. }\end{array}$ & 0.658 \\
\hline & V22 Bank staff is educated. & 0.503 \\
\hline & $\begin{array}{l}\text { V35 Account debits occur only with my prior } \\
\text { authorization. }\end{array}$ & 0.522 \\
\hline EMPATHY & $\begin{array}{l}\text { V9 When I have some problem with the Bank they are } \\
\text { supportive }\end{array}$ & 0.537 \\
\hline \multirow[t]{5}{*}{$\alpha=0.872$} & V27 Bank employees know my company's needs. & 0.451 \\
\hline & $\begin{array}{l}\text { V28 The Bank has the interests of my company as an } \\
\text { objective. }\end{array}$ & 0.516 \\
\hline & $\begin{array}{l}\text { V29 The Bank has convenient business hours for all its } \\
\text { customers. }\end{array}$ & 0.631 \\
\hline & $\begin{array}{l}\text { V39 The provision of resources in credit operations } \\
\text { occurs immediately. }\end{array}$ & 0.609 \\
\hline & $\begin{array}{l}\text { V40 The commuting to the branch to sign documents } \\
\text { (contracts and registrations) does not bother me }\end{array}$ & 0.616 \\
\hline INTERNET & V6 The Bank's internet banking is always working. & 0.818 \\
\hline \multirow[t]{2}{*}{$\alpha=0.949$} & V7 The Bank's internet banking is easy to use. & 0.808 \\
\hline & $\begin{array}{l}\text { V33The Bank's internet banking gives me } \\
\text { convenience. }\end{array}$ & 0.639 \\
\hline
\end{tabular}

Table 2 presents the results associated to Loyalty Factor. 
Table 2. Loyalty Factor.

\begin{tabular}{llc}
\hline \multicolumn{1}{c}{ FATOR } & \multicolumn{1}{c}{ VARIABLES } & LOADING \\
\hline LEALDADE & $\begin{array}{l}\text { V41 I will use the Bank service again when } \\
\text { necessary. }\end{array}$ & 0.825 \\
\hline$\alpha=0.917$ & $\begin{array}{l}\text { V42 I will recommend the Bank to friends, } \\
\text { neighbors and relatives. }\end{array}$ & 0.936 \\
\hline & $\begin{array}{l}\text { V45 I will have a larger business amount with the } \\
\text { Bank in the future. }\end{array}$ & 0.933 \\
\hline & $\begin{array}{l}\text { V46 I will consider the Bank as my first choice in } \\
\text { the purchase of some banking service }\end{array}$ \\
\hline
\end{tabular}

\subsection{Perceived quality and loyalty}

Multiple regression analysis has been executed to measure linear relations between perceived quality and loyalty, specifically to what extent quality factors (independent variables) may explain loyalty (dependent variable). Table 3 presents those results, in which it is possible to verify that Empathy, Assurance and Responsiveness have significant association with Loyalty, with standardized coefficients $(\beta)$ statistically significant.

Table 3. Relations between Quality and Loyalty Factors.

\begin{tabular}{cccc}
\hline Factor & $\boldsymbol{\beta}$ (Stand. Coef) & $\mathbf{t}$ & Significance \\
\hline Empathy & 0.368 & 3.506 & 0.001 \\
\hline Assurance & 0.267 & 2.925 & 0.004 \\
\hline Responsiveness & 0.218 & 2.099 & 0.038 \\
\hline Reliability & -0.044 & -0.463 & 0.644 \\
\hline Tangibles & 0.068 & 1.009 & 0.315 \\
\hline Internet & 0.038 & 0.578 & 0.564 \\
\hline
\end{tabular}

In order to estimate the regression model, we have executed stepwise method with a 0.05 significance level. The model presented in Table 3 has achieved a 0.616 adjusted $\mathrm{R}^{2,}$; in other words $61.6 \%$ of loyalty variance is explained by the variance of empathy, assurance and responsiveness factors. Similar study performed with banking natural person users (Vera \& Trujillo, 2013) also confirmed assurance and empathy as independent variables with explanation power on loyalty. On the other hand, Kheng et al. (2010) got significant results with reliability, empathy and assurance, and Malik et al. (2011) identified that tangibles, assurance and empathy, but not reliability and responsiveness, contributed to expand loyalty.

Other studies, such as Choudhury (2013) and Kaura et al. (2015), considered other factors. Choudhury (2013) found stronger relation between the factors employees' behavior and reliability with repurchase intentions, while tangibles and convenience presented lower explanation power. Kaura et al. (2015) identified significant relation between employee's behavior and information technology with loyalty, excepting tangibles. In the works of both Choudhury (2013) and Kaura et al. (2015) we have identified a similarity between employee's behavior factor and empathy factor considered in our study, as well as the lower explanation power of tangibles in loyalty. 


\subsection{Differences between groups}

In this study we have also identified means' differences from the researched factors with the sample features through ANOVA, with a 0.05 significance level, whose results are presented in Table 4. The sample groups "customers that operate with more than a bank" and "company's segment" have not presented any significant effect on their behaviors. Those customers operating with more banks do not influence on their quality and loyalty evaluation.

With regard to results which presented factors with significance in explaining companies' behaviors (quality and loyalty), we highlight the groups "customers that operate with bank's credit" and customers that have the bank as the main financial institution in business amount", out of which six and seven presented statistical significance. We may state that quality was better perceived and loyalty presented a larger level for customers that use one of the main banking services and have the bank as their main financial provider.

Customers that have the bank as the main provider have higher means in the five quality factors, internet and loyalty, when compared with those that do not have the bank as the main provider. For customers operating with credit with the bank, only Internet has not shown statistical difference, which reinforces the strong association between banking services and credit provision.

Regarding the group "customers that issue bank payments slips", the factors assurance and loyalty have presented significant differences, with higher means for those that issue. Among the customers that use internet banking for payments, only loyalty has shown explanation power. Those using internet banking have higher means, which may be associated to the importance of offering a variety of services to guarantee a higher loyalty. The absence of the relation with internet and quality factors can be explained by Reguera-Alvarado et al. (2016), who state that for customers with more banking investments the use of e-banking did not influence the relationship quality, as they acquire more personalized attention in banking services. In our research, we stress that $80 \%$ of customers that have more business amount with the bank uses internet banking.

In the group that needs face-to-face bank teller services three factors have presented statistical significance: assurance, internet and loyalty, with higher means for those who use the services. We highlight the fact that those using bank teller services have a better perception of internet.

The group with the bank as the main provider, represented by 59 customers in 101 companies that work with more than a bank $(58.42 \%)$, have achieved all factors with explanation power, which can be explained by the relationship level, once the sample operating with more than a bank (yes/no) has not presented significant differences (data not presented in the table). These results provide a reasonable explanation for a behavior of preference, which corroborates Bapat (2015), who states that customers with more than one account maintain loyalty relation with their preferred banks, and Seiler et al. (2013), in which customers with more investments present more levels of satisfaction and loyalty.

In relation to the frequency of time in the branch for discussing company's matters, an aspect associated to relationship intensity, the factor tangibles has shown explanation power. Customers who go daily, weekly and fortnightly to branches, represented by 56 out of 125 respondents (44.8\%), have presented higher means compared with those who goes at most once a month. Physical branches emerge as the favorite channel for emotional interactions, in which human interactions play an 
important role (Bapat, 2017). Another aspect to highlight is about the absence of explanation power for loyalty, in other words, customers who go more to branches are not necessarily more loyal.

"Frequency of account managers' visits to companies" have presented four factors with significance: tangibles, responsiveness, empathy and loyalty. We reinforce the lower means from the 96 customers out of 123 (78.0\%) visited less than once a month, associated to the constructs response, empathy and loyalty, with a relational nature. According to Zacharias et al. (2008), customer satisfaction depends, at least in part, on the way banks interact with customers and manage relationships, involving both managers' services and problems' solving. Tan et al. (2017) also emphasize the role of employees on customers' perceptions about service quality.

With regard to customers that have an account for over 10 years, reliability has shown explanation power, with higher means in comparison to customers with fewer relationship years. The need of trust for the existence of long lasting relationships becomes clear, but the non-significant result related to loyalty deserves to be stressed as well.

Table 4. ANOVA between sample groups.

\begin{tabular}{|c|c|c|c|c|c|c|c|c|c|}
\hline 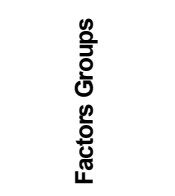 & & & 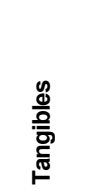 & 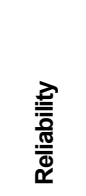 & 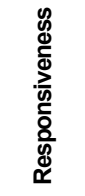 & 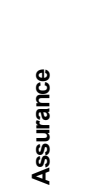 & 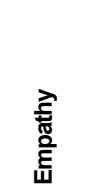 & 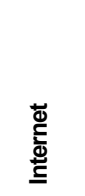 & $\frac{\frac{7}{9}}{\frac{7}{0}}$ \\
\hline \multirow{6}{*}{$\begin{array}{l}\text { Operates with } \\
\text { Credit }\end{array}$} & \multirow{3}{*}{ Yes } & $\mathrm{N}$ & 97 & 97 & 97 & 97 & 97 & 97 & 97 \\
\hline & & Mean & *5.801 & *5.865 & *5.888 & ${ }^{*} 6.205$ & *5.575 & 5.842 & ${ }^{*} 6.052$ \\
\hline & & St. Deviat. & 1.003 & 0.939 & 0.967 & 0.782 & 1.021 & 0.993 & 1.042 \\
\hline & \multirow{3}{*}{ No } & $\mathrm{N}$ & 29 & 29 & 29 & 29 & 29 & 29 & 29 \\
\hline & & Mean & *5.195 & *5.276 & *4.943 & *5.523 & *4.475 & 5.415 & ${ }^{*} 5.094$ \\
\hline & & St. Deviat. & 1.146 & 1.011 & 1.170 & 0.915 & 1.269 & 1.205 & 1.527 \\
\hline \multirow{6}{*}{$\begin{array}{l}\text { Issues Bank } \\
\text { Payments Slips }\end{array}$} & \multirow{3}{*}{ Yes } & $\mathrm{N}$ & 71 & 71 & 71 & 71 & 71 & 71 & 71 \\
\hline & & Mean & 5.807 & 5.792 & 5.775 & *6.217 & 5.511 & 5.776 & ${ }^{*} 6.073$ \\
\hline & & St. Deviat. & 0.974 & 0.956 & 1.045 & 0.712 & 1.081 & 1.058 & 0.935 \\
\hline & \multirow{3}{*}{ No } & $\mathrm{N}$ & 55 & 55 & 55 & 55 & 55 & 55 & 55 \\
\hline & & Mean & 5.503 & 5.667 & 5.589 & *5.900 & 5.124 & 5.714 & ${ }^{*} 5.602$ \\
\hline & & St. Deviat. & 1.162 & 1.030 & 1.136 & 0.927 & 1.258 & 1.073 & 1.440 \\
\hline \multirow{6}{*}{$\begin{array}{l}\text { Uses Internet } \\
\text { Banking for } \\
\text { payments }\end{array}$} & \multirow{3}{*}{ Yes } & $\mathrm{N}$ & 94 & 94 & 94 & 94 & 94 & 94 & 94 \\
\hline & & Mean & 5.709 & 5.762 & 5.737 & 6.137 & 5.388 & 5.859 & ${ }^{*} 6.042$ \\
\hline & & St. Deviat. & 0.971 & 0.994 & 1.008 & 0.779 & 1.158 & 0.989 & 1.038 \\
\hline & \multirow{3}{*}{ No } & $\mathrm{N}$ & 32 & 32 & 32 & 32 & 32 & 32 & 32 \\
\hline & & Mean & 5.583 & 5.686 & 5.515 & 5.832 & 5.186 & 5.489 & ${ }^{*} 5.244$ \\
\hline & & St. Deviat. & 1.314 & 1.109 & 1.323 & 1.056 & 1.240 & 1.201 & 1.564 \\
\hline \multirow{6}{*}{$\begin{array}{l}\text { Face-to-face } \\
\text { bank teller } \\
\text { service }\end{array}$} & \multirow{3}{*}{ Yes } & $\mathrm{N}$ & 72 & 72 & 72 & 72 & 72 & 72 & 72 \\
\hline & & Mean & 5.796 & 5.877 & *5.877 & 6.148 & 5.502 & *5.916 & ${ }^{*} 6.080$ \\
\hline & & St. Deviat. & 1.094 & 1.023 & 1.059 & 0.901 & 1.133 & 1.029 & 1.120 \\
\hline & \multirow{3}{*}{ No } & $\mathrm{N}$ & 55 & 55 & 55 & 55 & 55 & 55 & 55 \\
\hline & & Mean & 5.503 & 5.553 & *5.411 & 5.934 & 5.109 & *5.541 & *5.527 \\
\hline & & St. Deviat. & 1.008 & 0.904 & 1.082 & 0.797 & 1.200 & 1.067 & 1.310 \\
\hline \multirow{3}{*}{$\begin{array}{l}\text { Bank as the } \\
\text { main financial } \\
\text { provider }\end{array}$} & \multirow{3}{*}{ Yes } & $\mathrm{N}$ & 59 & 59 & 59 & 59 & 59 & 59 & 59 \\
\hline & & Mean & *6.005 & ${ }^{*} 6.008$ & *5.885 & *6.219 & *5.548 & *6.111 & ${ }^{*} 6.180$ \\
\hline & & St. Deviat. & 0.896 & 0.890 & 1.078 & 0.903 & 1.263 & 0.800 & 0.997 \\
\hline
\end{tabular}


Table 4. Continued...

\begin{tabular}{|c|c|c|c|c|c|c|c|c|c|}
\hline 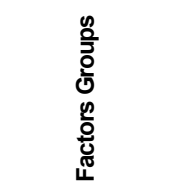 & & & 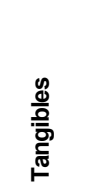 & 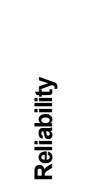 & 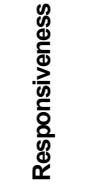 & 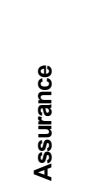 & 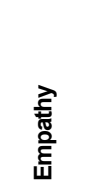 & 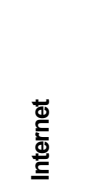 & $\frac{\frac{9}{9}}{\frac{3}{\sqrt[0]{0}}}$ \\
\hline & & $\mathrm{N}$ & 42 & 42 & 42 & 42 & 42 & 42 & 42 \\
\hline & No & Mean & *5.024 & *5.404 & *5.414 & *5.868 & *4.949 & *5.401 & ${ }^{*} 5.290$ \\
\hline & & St. Deviat. & 1.137 & 0.979 & 1.056 & 0.785 & 1.044 & 1.220 & 1.388 \\
\hline \multirow{6}{*}{$\begin{array}{l}\text { Frequency in } \\
\text { the branch }\end{array}$} & \multirow{3}{*}{$\begin{array}{l}\text { Mininum } \\
\text { fortnightly }\end{array}$} & $\mathrm{N}$ & 56 & 56 & 56 & 56 & 56 & 56 & 56 \\
\hline & & Mean & ${ }^{*} 6.006$ & 5.852 & 5.846 & 6.211 & 5.535 & 5.895 & 5.897 \\
\hline & & St. Deviat. & 0.873 & 1.036 & 1.157 & 0.847 & 1.127 & 1.100 & 1.275 \\
\hline & \multirow{3}{*}{$\begin{array}{l}\text { Maximum } \\
\text { monthly }\end{array}$} & $\mathrm{N}$ & 69 & 69 & 69 & 69 & 69 & 69 & 69 \\
\hline & & Mean & *5.382 & 5.633 & 5.546 & 5.928 & 5.157 & 5.632 & 5.773 \\
\hline & & St. Deviat. & 1.135 & 0.946 & 1.033 & 0.861 & 1.205 & 1.024 & 1.214 \\
\hline \multirow{6}{*}{$\begin{array}{l}\text { Bank managers' } \\
\text { visits }\end{array}$} & \multirow{3}{*}{$\begin{array}{l}\text { Mininum } \\
\text { monthly }\end{array}$} & $\mathrm{N}$ & 27 & 27 & 27 & 27 & 27 & 27 & 27 \\
\hline & & Mean & ${ }^{*} 6.037$ & 5.988 & *6.132 & 6.247 & *5.743 & 5.615 & ${ }^{*} 6.233$ \\
\hline & & St. Deviat. & 0.786 & 0.887 & 0.925 & 0.644 & 0.935 & 1.258 & 0.890 \\
\hline & \multirow{3}{*}{$\begin{array}{c}\text { Maximum } \\
\text { monthly }\end{array}$} & $\mathrm{N}$ & 96 & 96 & 96 & 96 & 96 & 96 & 96 \\
\hline & & Mean & *5.541 & 5.658 & *5.550 & 5.988 & ${ }^{*} 5.202$ & 5.792 & ${ }^{*} 5.690$ \\
\hline & & St. Deviat. & 1.117 & 1.007 & 1.112 & 0.913 & 1.227 & 1.014 & 1.299 \\
\hline \multirow{6}{*}{$\begin{array}{l}\text { Length of } \\
\text { account }\end{array}$} & \multirow{3}{*}{$\begin{array}{l}\text { Up to } 10 \\
\text { years }\end{array}$} & $\mathrm{N}$ & 70 & 70 & 70 & 70 & 70 & 70 & 70 \\
\hline & & Mean & 5.609 & *5.576 & 5.519 & 5.982 & 5.142 & 5.637 & 5.745 \\
\hline & & St. Deviat. & 1.059 & 1.017 & 1.189 & 0.935 & 1.232 & 1.117 & 1.298 \\
\hline & \multirow{3}{*}{$\begin{array}{c}\text { More than } \\
10 \text { years }\end{array}$} & $\mathrm{N}$ & 56 & 56 & 56 & 56 & 56 & 56 & 56 \\
\hline & & Mean & 5.726 & *5.921 & 5.861 & 6.130 & 5.548 & 5.877 & 5.940 \\
\hline & & St. Deviat. & 1.077 & 0.914 & 0.924 & 0.758 & 1.066 & 0.968 & 1.148 \\
\hline \multirow{6}{*}{$\begin{array}{l}\text { Numer of } \\
\text { company's } \\
\text { employees }\end{array}$} & \multirow{3}{*}{ Up to 9} & $\mathrm{~N}$ & 54 & 54 & 54 & 54 & 54 & 54 & 54 \\
\hline & & Mean & 5.716 & 5.703 & 5.580 & *5.849 & 5.223 & 5.593 & 5.755 \\
\hline & & St. Deviat. & 1.109 & 0.989 & 1.173 & 0.961 & 1.281 & 1.149 & 1.344 \\
\hline & \multirow{3}{*}{10 or more } & $\mathrm{N}$ & 71 & 71 & 71 & 71 & 71 & 71 & 71 \\
\hline & & Mean & 5.615 & 5.735 & 5.726 & "6.186 & 5.732 & 5.845 & 5.874 \\
\hline & & St. Deviat. & 1.037 & 0.985 & 1.026 & 0.748 & 1.079 & 0.976 & 1.149 \\
\hline
\end{tabular}

*Significant differences in a 0.05 significance level. N: Number of cases.

In general, loyalty has shown explanation power on six out of nine analyzed sample groups (operates with credit, issues payment slips, uses internet banking, uses faceto-face bank teller services, the bank as the main provider and managers' visits), being those that have presented more occurrences of significant differences in relation to the other analyzed constructs. These sample groups are associated to bank services and relationship.

The factors tangibles, responsiveness and assurance have presented four occurrences each, mainly with the sample groups operates with credit, bank as the main provider and managers' visits. Reliability and empathy have shown three occurrences each and internet two occurrences of significance.

About all these occurrences, we have identified higher means with customers who use banking services, such as credit, bank payment slips, internet banking, face-to-face service, when the bank is the main financial provider or when there are more managers' visits. Quality has been better perceived by those customers that most use banking services, which influences in loyalty levels (Bapat, 2015; Seiler et al., 2013). 


\section{Concluding remarks}

In a context of service operations, this study has verified the interference of perceived quality on loyalty of corporate person customers in a bank. Service operations generate a challenging environment to organizations, because contact, interaction and customer involvement bring complexity to operation management (Prajogo, 2006).

Studies have suggested that there is a relation between service quality and behavioral aspects of customers, such as loyalty, affected positively by service quality (Zeithaml et al., 1996; Bloemer et al., 1999). Since loyalty is considered a valuable means to guarantee sustainable and constant profits (Reichheld, 1996; Heskett et al., 1994), we reinforce the theme relevance both in theory and practice, presenting some contributions and reflections.

In theory and research, this study shows a case with execution of a mixed method, qualitative and quantitative, in search of a greater explanation of banking operation services, specifically in corporate person segment. Both research approaches are justified due to the specificities involved in service operations. This study can contribute in future research studies considering similar research strategies. Moreover, we present perceived quality in a specific segment of customers in banking (corporate person), as suggested by Ribeiro et al. (2010), as well as a proposal of perceived quality in order to explain loyalty in banking services (Souza et al., 2013).

In this concern, we highlight the suitability of considering SERVPERF constructs for quality evaluation in services that impact on loyalty, mainly empathy, assurance and responsiveness. Furthermore, we have included to the original scale items associated to front-line and back offices, as well as aspects associated to internet. Still, the study corroborates previous studies that identified the direct and positive relation between quality and loyalty (Hafeez \& Muhammad, 2012; Malik et al., 2011; Mittal \& Gera, 2012; Ladhari et al., 2011).

This study brings into the context of perceived quality elements associated to operation services per se, including back office. Moreover, it reinforces the continuity of studies in banking service quality, which still need consistency in evaluation and production levels (Ensslin et al., 2013).

With regard to managerial implications, this study shows some practical contributions to banking managers, specifically to corporate customers, but that can be also considered to individuals, taking into account some considerations. The identification of service quality factors, which helps to explain loyalty, can be used to deal with strategies and attitudes that promote the maintenance of a sustainable customer base. Knowing about customers' interests at the moment they evaluate quality of a service helps to meet market needs and to be more competitive.

As research limitations, once we have associated two constructs, perceived quality and loyalty, the inclusion of other ones, such as perceived value and switching costs, could contribute to enlarge the explanation of loyalty, although the suitable $\mathrm{R}^{2}$ achieved in our research. Furthermore, we have focus on a specific segment of customers (corporate person), in a specific bank, and our sample is non-probabilistic. In this regard, as suggestions, research studies focusing on more specific samples, for example customer's segment of activity or revenue levels. Future studies also can involve new constructs, such as perceived value and switching costs, through structural equation modelling, with multigroup analysis between corporate customers and end users. Studies that involve the relation between service quality and loyalty moderated by the use of technological banking devices or apps are recommended as well. 


\section{References}

Abdullah, F., Suhaimi, R., Saban, G., \& Hamali, J. (2011). Bank service quality (BSQ) index: an indicator of service performance. International Journal of Quality \& Reliability Management, 28(5), 542-555. http://dx.doi.org/10.1108/02656711111132571.

Aksu, A. A. (2006). Gap analysis in customer loyalty: a research in 5-star hotels in the Antalya region of Turkey. Quality \& Quantity, 40(2), 187-205. http://dx.doi.org/10.1007/s11135-0055357-y.

Al-Hawari, M. A. (2015). How the personality of retail bank customers interferes with the relationship between service quality and loyalty. International Journal of Bank Marketing, 33(1), 41-57. http://dx.doi.org/10.1108/IJBM-09-2013-0096.

Assael, H. (1992). Consumer behavior and marketing - patterns, types, segmentation. Boston: PWS Kent.

Balbim, A., Jr., \& Bornia, A. C. (2011). Proposta de um instrumento de medida para avaliar a satisfação de clientes de bancos utilizando a Teoria da Resposta ao Item. Gestão \& Produção, 18(3), 541-554. http://dx.doi.org/10.1590/S0104-530X2011000300008.

Bapat, D. (2015). Primary bank as a measure of brand loyalty: an empirical study in Indian retail banking context. Journal of Services Research, 15(1), 57.

Bapat, D. (2017). Exploring the antecedents of loyalty in the context of multi-channel banking. International Journal of Bank Marketing, 35(2), 174-186. http://dx.doi.org/10.1108/lJBM-102015-0155.

Bardin, L. (2011). Análise de conteúdo. São Paulo: Edições 70.

Barreto, J., \& Martins, R. S. (2018). Customer participation in professional services operations and its impacts on flexibility and costs. Brazilian Business Review, 15(1), 33-46. http://dx.doi.org/10.15728/bbr.2018.15.1.3.

Baumann, C., Hoadley, S., Hamin, H., \& Nugraha, A. (2017). Competitiveness vis-à-vis service quality as drivers of customer loyalty mediated by perceptions of regulation and stability in steady and volatile markets. Journal of Retailing and Consumer Services, 36, 62-74. http://dx.doi.org/10.1016/j.jretconser.2016.12.005.

Bloemer, J., De Ruyter, K. O., \& Wetzels, M. (1999). Linking perceived service quality and service loyalty: a multi-dimensional perspective. European Journal of Marketing, 33(11/12), 1082-1106. http://dx.doi.org/10.1108/03090569910292285.

Carlzon, J. (2005). A hora da verdade. Rio de Janeiro: Sextante.

Central Intelligence Agency - CIA. (2018). The World Factbook. Retrieved in 2018, May 15, from https://www.cia.gov/library/publications/the-world-factbook/geos/nl.html

Chase, R. B., \& Apte, U. M. (2007). A history of research in service operations: what's the big idea? Journal of Operations Management, 25(2), 375-386. http://dx.doi.org/10.1016/j.jom.2006.11.002.

Chase, R. B., Aquilano, N. J., \& Jacobs, R. (1998). Operations management for competitive advantage. Boston: McGraw-Hill Irwin.

Choudhury, K. (2013). Service quality and customers' purchase intentions: an empirical study of the Indian banking sector. International Journal of Bank Marketing, 31(7), 529-543. http://dx.doi.org/10.1108/lJBM-02-2013-0009.

Collis, J., \& Hussey, R. (2005). Pesquisa em administração: um guia prático para alunos de graduação e pós-graduação. Porto Alegre: Bookman.

Creswell, J. W. (2010). Projeto de pesquisa métodos qualitativo, quantitativo e misto. Porto Alegre: Artmed.

Cronin, J. J., Jr., \& Taylor, S. A. (1992). Measuring service quality: a reexamination and extension. Journal of Marketing, 56(3), 55-68.

http://dx.doi.org/10.1177/002224299205600304. 
Dahiyat, S. E., Akroush, M. N., \& Abu-Lail, B. N. (2011). An integrated model of perceived service quality and customer loyalty: an empirical examination of the mediation effects of customer satisfaction and customer trust. International Journal of Services and Operations Management, 9(4), 453-490. http://dx.doi.org/10.1504/IJSOM.2011.041242.

Ensslin, L., Ensslin, S. R., \& Pinto, H. M. (2013). Processo de investigação e análise bibliométrica: avaliação da Qualidade dos Serviços Bancários. Revista de Administração Contemporânea, 17(3), 325-349. http://dx.doi.org/10.1590/S1415-65552013000300005.

Fitzsimmons, J. A., \& Fitzsimmons, M. J. (2014). Administração de serviços: operações, estratégia e tecnologia da informação. Porto Alegre: AMGH Editora.

Flick, U. (2009). Pesquisa qualitativa e quantitativa. Introdução à pesquisa qualitativa (3a ed.). Porto Alegre: Artmed.

Gremler, D. D., \& Brown, S. W. (1996). Service loyalty: its nature, importance, and implications. Advancing Service Quality: a Global Perspective, 5, 171-181.

Grönroos, C. (2009). Marketing: gerenciamento e serviços (3a ed.). Rio de Janeiro: Elsevier.

Hafeez, S., \& Muhammad, B. (2012). The Impact of service quality, customer satisfaction and Loyalty Programs on Customer's Loyalty: evidence from banking sector of Pakistan. International Journal of Business and Social Science, 3(16)

Hair, J. F., Jr., Black, W. C., Babin, B. J., Anderson, R. E., \& Tatham, R. L. (2009). Análise multivariada de dados. Porto Alegre: Bookman Editora.

Hamzah, Z. L., Lee, S. P., \& Moghavvemi, S. (2017). Elucidating perceived overall service quality in retail banking. International Journal of Bank Marketing, 35(5), 781-804. http://dx.doi.org/10.1108/lJBM-12-2015-0204.

Henrique, J. L., \& Matos, C. A. D. (2015). The influence of personal values and demographic variables on customer loyalty in the banking industry. International Journal of Bank Marketing, 33(4), 571-587. http://dx.doi.org/10.1108/lJBM-06-2014-0082.

Heskett, J. L. (2002). Beyond customer loyalty. Managing Service Quality, 12(6), 355-357. http://dx.doi.org/10.1108/09604520210451830.

Heskett, J. L., Jones, T. O., Loveman, G. W., Sasser, W. E., \& Schlesinger, L. A. (1994). Putting the service-profit chain to work. Harvard Business Review, 72(2), 164-174.

Instituto Brasileiro de Geografia e Estatística - IBGE. (2018). Sistema de Contas Nacionais Trimestrais - SCNT. Retrieved in 2018, May 15, from https://www.ibge.gov.br/estatisticasnovoportal/economicas/contas-nacionais/9300-contas-nacionaistrimestrais.html $?=\& \mathrm{t}=$ resultados

Jaiswal, A. K., \& Lemmink, J. G. (2017). Investigating a comparative evaluation approach in explaining loyalty. Marketing Intelligence \& Planning, 35(7), 937-954. http://dx.doi.org/10.1108/MIP-03-2017-0061.

Johnston, R. (2005). Service operations management: from the roots up. International Journal of Operations \& Production Management, 25(12), 1298-1308. http://dx.doi.org/10.1108/01443570510633666.

Johnston, R., \& Clark, G. (2002). Administração de operações de serviço. São Paulo: Atlas.

Karatepe, O. M., Yavas, U., \& Babakus, E. (2005). Measuring service quality of banks: scale development and validation. Journal of Retailing and Consumer Services, 12(5), 373-383. http://dx.doi.org/10.1016/j.jretconser.2005.01.001.

Kaura, V., Prasad, D., \& Sharma, S. (2015). Service quality, service convenience, price and fairness, customer loyalty, and the mediating role of customer satisfaction. International Journal of Bank Marketing, 33(4), 404-422. http://dx.doi.org/10.1108/IJBM-04-2014-0048.

Kheng, L. L., Mahamad, O., Ramayah, T., \& Mosahab, R. (2010). The impact of service quality on customer loyalty: a study of banks in Penang, Malaysia. International Journal of Marketing Studies, 2(2), 57-66. 
Kline, R. B. (2011). Principles and practice of structural equation modeling (3rd ed.). New York: The Gilford Press.

Kranias, A., \& Bourlessa, M. (2013). Investigating the relationship between service quality and loyalty in Greek banking sector. Procedia Economics and Finance, 5, 453-458. http://dx.doi.org/10.1016/S2212-5671(13)00053-1.

Ladhari, R., Souiden, N., \& Ladhari, I. (2011). Determinants of loyalty and recommendation: the role of perceived service quality, emotional satisfaction and image. Journal of Financial Services Marketing, 16(2), 111-124. http://dx.doi.org/10.1057/fsm.2011.10.

LaGanga, L. R. (2011). Lean service operations: reflections and new directions for capacity expansion in outpatient clinics. Journal of Operations Management, 29(5), 422-433. http://dx.doi.org/10.1016/j.jom.2010.12.005.

Larentis, F., Tondolo, V. A. G., Cislaghi, T. P., \& Camargo, M. E. (2013). Contribuição dos relacionamentos interorganizacionais às operações de serviços: um estudo de casos múltiplos. Revista Eletrônica de Estratégia \& Negócios, 6(3), 156-181. http://dx.doi.org/10.19177/reen.v6e32013156-181.

Lee, G. Y., Chu, P. Y., \& Chao, Y. (2011). Service quality, relationship quality, and customer loyalty in Taiwanese Internet banks. Social Behavior and Personality, 39(8), 1127-1139. http://dx.doi.org/10.2224/sbp.2011.39.8.1127.

Lovelock, C., \& Wirtz, L. (2006). Marketing de serviços: tecnologia e resultados. São Paulo: Pearson.

Makanyeza, C., \& Chikazhe, L. (2017). Mediators of the relationship between service quality and customer loyalty: evidence from the banking sector in Zimbabwe. International Journal of Bank Marketing, 35(3), 540-556. http://dx.doi.org/10.1108/IJBM-11-2016-0164.

Malhotra, N. K. (2012). Pesquisa de marketing: uma orientação aplicada. Porto Alegre: Bookman Editora.

Malik, M. E., Naeem, B., \& Arif, Z. (2011). Impact of perceived service quality on banking customers' loyalty. Interdisciplinary Journal of Contemporary Research in Business, 3(8), 637-645.

Mangini, E. R., Urdan, A. T., \& Santos, A. (2017). Da qualidade em serviços à lealdade: perspectiva teórica do comportamento do consumidor. Revista Brasileira de Marketing, 16(2), 207-217.

Mittal, S., \& Gera, R. (2012). Relationship between service quality dimensions and behavioural intentions: an SEM study of public sector retail banking customers in India. Journal of Services Research, 12(2), 147.

Oliver, R. L. (1999). Whence consumer loyalty? Journal of Marketing, 63(4 Suppl 1), 33-44. http://dx.doi.org/10.1177/00222429990634s105.

Parasuraman, A., Zeithaml, V. A., \& Berry, L. L. (1985). A conceptual model of service quality and its implications for future research. Journal of Marketing, 49(4), 41-50. http://dx.doi.org/10.1177/002224298504900403.

Parasuraman, A., Zeithaml, V. A., \& Berry, L. L. (1994). Reassessment of expectations as a comparison standard in measuring service quality: implications for further research. Journal of Marketing, 58(1), 111-124. http://dx.doi.org/10.1177/002224299405800109.

Parasuraman, A., Zeithaml, V., \& Berry, L. L. (1988). Servqual: a multiple-item scale for measuring consumer perceptions of service quality. Journal of Retailing, 64, 12-40.

Pattanayak, D., Koilakuntla, M., \& Punyatoya, P. (2017). Investigating the influence of TQM, service quality and market orientation on customer satisfaction and loyalty in the Indian banking sector. International Journal of Quality \& Reliability Management, 34(3), 362-377. http://dx.doi.org/10.1108/IJQRM-04-2015-0057. 
Ponsignon, F., Smart, P. A., \& Maull, R. S. (2011). Service delivery system design: characteristics and contingencies. International Journal of Operations \& Production Management, 31(3), 324-349. http://dx.doi.org/10.1108/01443571111111946.

Prajogo, D. (2006). The implementation of operations management techniques in service organisations: an Australian perspective. International Journal of Operations \& Production Management, 36(12), 1374-1390. http://dx.doi.org/10.1108/01443570610710597.

Reguera-Alvarado, N., Blanco-Oliver, A., \& Martín-Ruiz, D. (2016). Testing the predictive power of PLS through cross-validation in banking. Journal of Business Research, 69(10), 46854693. http://dx.doi.org/10.1016/j.jbusres.2016.04.016.

Reichheld, F. F. (1996). A estratégia da lealdade: a força invisível que mantém clientes e funcionários e sustenta crescimento, lucros e valor. Rio de Janeiro: Campus.

Reichheld, F. F., \& Sasser, J. W., Jr. (1990). Zero defections: quality comes to services. Harvard Business Review, 68(5), 105-111. PMid:10107082.

Ribeiro, J. L. D., Machado, C. O., \& Tinoco, M. A. C. (2010). Determinantes da satisfação e atributos da qualidade em serviços bancários. Gestão \& Produção, 17(4), 775-790. http://dx.doi.org/10.1590/S0104-530X2010000400011.

Robledo, M. A. (2001). Measuring and managing service quality: integrating customer expectations. Managing Service Quality, 11(1), 22-31. http://dx.doi.org/10.1108/09604520110379472.

Roth, A. V., \& Menor, L. J. (2003). Insights into service operations management: a research agenda. Production and Operations Management, 12(2), 145-164. http://dx.doi.org/10.1111/j.1937-5956.2003.tb00498.x.

Santos, C. P. D. (2001). Impacto do gerenciamento de reclamações na confiança e lealdade do consumidor, no contexto de trocas relacionais de serviços: construção e teste de um modelo teórico (Tese de doutorado). Universidade Federal do Rio Grande do Sul, Porto Alegre.

Santos, C. P. D., \& Fernandes, D. V. D. H. (2006). A recuperação de serviços como ferramenta de relacionamento e seu impacto na confiança e lealdade dos clientes. Revista de Administração de Empresas, 48(1), 10-24.

Seiler, V., Rudolf, M., \& Krume, T. (2013). The influence of socio-demographic variables on customer satisfaction and loyalty in the private banking industry. International Journal of Bank Marketing, 31(4), 235-258. http://dx.doi.org/10.1108/IJBM-10-2012-0101.

Seth, N., Deshmukh, S. G., \& Vrat, P. (2005). Service quality models: a review. International Journal of Quality \& Reliability Management, 22(9), 913-949. http://dx.doi.org/10.1108/02656710510625211.

Sirdeshmukh, D., Singh, J., \& Sabol, B. (2002). Consumer trust, value, and loyalty in relational exchanges. Journal of Marketing, 66(1), 15-37. http://dx.doi.org/10.1509/jmkg.66.1.15.18449.

Souto, C. M., \& Correia-Neto, J. S. (2017). Qualidade de serviços: uma análise comparativa entre SERVQUAL e SERVPERF. Journal of Perspectives in Management, 1(1), 63-73.

Souza, B. B. P., Gosling, M. M., \& Gonçalves, C. A. (2013). Mensuração do mix de marketing de serviços, da satisfação e da lealdade em clientes de um banco de varejo. Revista Brasileira de Marketing, 12(2), 108-132. http://dx.doi.org/10.5585/remark.v12i2.2337.

Tan, L. H., Hamid, S. R., \& Chew, B. C. (2017). Exploring manager's perspective of service quality strategies in Malaysian Banking Industry. Journal of Strategic Marketing, 25(1), 3148. http://dx.doi.org/10.1080/0965254X.2015.1076878.

Vera, J., \& Trujillo, A. (2013). Service quality dimensions and superior customer perceived value in retail banks: an empirical study on Mexican consumers. Journal of Retailing and Consumer Services, 20(6), 579-586. http://dx.doi.org/10.1016/j.jretconser.2013.06.005. 
Visentini, M. S., \& Fenner, V. U. (2017). Lealdade: análise da produção científica brasileira na área de marketing no período compreendido entre 2010 e 2016. Perspectivas em Gestão \& Conhecimento, 7(2), 175-198.

Zacharias, M. L. B., Figueiredo, K. F., \& Almeida, V. M. C. (2008). Determinantes da satisfação dos clientes com serviços bancários. RAE Eletrônica, 7(2). http://dx.doi.org/10.1590/S1676-56482008000200002.

Zeithaml, V. A. (1988). Consumer perceptions of price, quality, and value: a means-end model and synthesis of evidence. Journal of Marketing, 52(3), 2-22. http://dx.doi.org/10.1177/002224298805200302.

Zeithaml, V. A., Berry, L. L., \& Parasuraman, A. (1996). The behavioral consequences of service quality. Journal of Marketing, 60(2), 31-46. http://dx.doi.org/10.1177/002224299606000203.

Zeithaml, V. A., Bitner, M. J., \& Gremler, D. D. (2014). Marketing de Serviços: A Empresa com Foco no Cliente. AMGH Editora. 